\title{
The Impact of Financial Liberalization on Economic Development: A Comparison Between China and Japan
}

\author{
Wenxuan Yang* \\ The Australian National University, Australia. E-mail: u6713198@anu.edu.au
}

Abstract: According to the theory of financial liberalization, effective financial reform and moderate regulation of financial market can promote economic development. Taking China and Japan as examples, this paper analyzes some problems in the current financial liberalization reform of the two countries. Simulation scenarios about financial reform are then applied to China and Japan using the GTAP computable general equilibrium model of the global economy. The simulation results show that reducing investment barriers and improving the efficiency of capital use in the industrial sector can effectively promote the economic growth of China and Japan above levels that would otherwise be achieved. Improving the efficiency of the financial sector service delivery would have an additional positive impact on the economies of both countries, albeit small compared to measures that promote gains across all sectors.

Keywords: Financial Liberalization; Economic Growth

\section{Introduction}

Economists have attributed the slow development of developing countries to the lack of capital for a long time. They believed that if developing countries want to achieve economic development, they will either need to increase their savings or introduce foreign capital to speed up capital formation. In the Harrod-Doma model, capital accumulation is regarded as a determinant of economic growth ${ }^{[14]}$. According to the new economic growth theory, capital's impetus to the economy is realized in the short term through demand for capital goods and the addition of capital capacity, while technological progress, efficient institutional change and human capital accumulation are the driving forces of ongoing economic growth. McKinnon (1973) and Shaw (1973), respectively, established a set of theories about "financial repression" and "financial deepening". These theories analyzed the slow development of developing countries from the perspective of capital efficiency. They conjectured that the financial restraint policy in developing countries has distorted capital markets, resulting in inefficient use of capital and thus impeding their economic growth. Financial deepening can increase both the deposit and lending interest rates, encourage people to save, promote the flow of funds to efficient investment, and then improve the efficiency of capital used ${ }^{[11]}$.

In the second half of the 20th century, many countries carried out financial market reforms and deregulated financial markets. The reforms in these countries provided empirical experience for the theory of financial liberalization. Financial liberalization reforms in some countries have promoted rapid economic development, such as Korea in the 1960s, Federal Republic of Germany and Japan in the $1970 \mathrm{~s}^{[11]}$. However, financial liberalization in some countries has led to economic instability ${ }^{[13]}$, such as the economic crises in Latin American countries in 1990s (Yang, 2007). The above examples show that financial liberalization is a double-edged sword for the economy. The analysis of financial li-

Copyright (C) 2020 Wenxuan Yang

doi: 10.18282/ff.v9i1.808

This is an open-access article distributed under the terms of the Creative Commons Attribution Non-Commercial License

(http://creativecommons.org/licenses/by-nc/4.0/), which permits non-commercial use, distribution, and reproduction in any medium, provided the original work is properly cited. 
beralization and economic development should be based on specific national conditions.

The research subjects of this paper are China and Japan. China is an upper middle-income country, while Japan is a high-income country. The system and development degree of these two countries are very different. As a developed country, Japan's financial market is mature. Therefore, Japan's experience of financial liberalization reform could be of great significance to China in its further economic develops and integrates with the global economy.

\section{Literature review}

Goldsmith (1969) compared the financial historical data of 35 countries in the world over the past century using a stock and flow index to measure the financial structure and development level of a country. For the first time, quantitative research and comparative study were conducted on the differences of financial development among different countries, revealing the role of financial deepening in promoting economic development ${ }^{[2]}$.

In 1973, McKinnon and Shaw respectively analyzed the financial situation of developing countries from different angles and reached the same conclusion: financial liberalization can contribute to economic growth.

McKinnon emphasized the role of positive real deposit interest rate in capital raising. In developing countries, only positive real deposit interest rates can stimulate the growth of savings, provide finance for real investment and promote economic growth. Empirical support for his policy recommendations comes mainly from Taiwan's financial reform in the early 1950s and South Korea's financial reform practice in the mid-1960s ${ }^{[1](p 105-116)}$.

Shaw paid more attention to the financing function of financial institutions and emphasizes the role of external financing in capital formation. He argued that raising deposit rates would increase the amount of money flowing to financial institutions, which was a prerequisite for increasing the supply of credit funds and investment. Shaw's theoretical contribution to financial liberalization focused on the role of financial intermediaries in economic development ${ }^{[12]}$.

Although the basic analysis between the two authors is different, the results are very similar, that is, the increase of real deposit interest rate promotes savings growth and contribute to economic growth through higher savings and investment.

\section{Broad framework}

The economic effects of financial liberalization can be summarized through three core factors: savings, investment, and the real output, which interact with each other and form the basis of achieving economic benefits through financial liberalization (Figure 1).

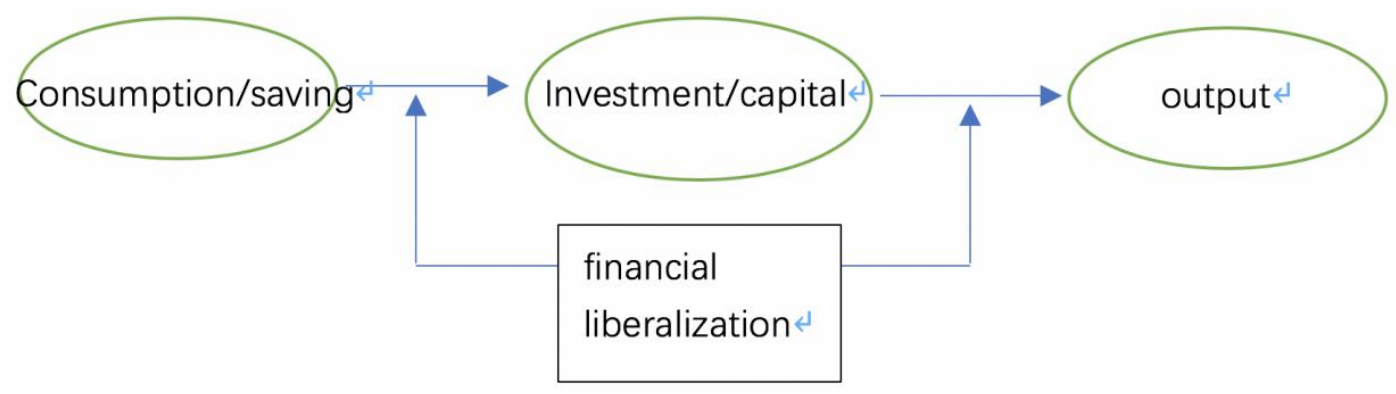

Figure 1. The influence path of financial liberalization on economy.

\subsection{Barriers to foreign capital investment}

Reducing investment barriers can promote economic growth. In an open economic system, the opening of capital account is an important part of liberalized financial system. Interest rate spread between different countries and exchange rates between different currencies are directly related to the flow of international capital. Foreign capital can augment domestic savings and contribute to the investment. Implementing financial liberalization, abolishing exchange 
rate control policy and promoting the free flow of international capital can effectively solve the problem of insufficient domestic savings, and help make foreign exchange capital play an active role in the domestic economy (as a simplified model, this paper does not consider the cost of capital flow among countries.).

Higher deposit interest rate can attract foreign capital (Figure 2). The price of capital can be measured by the real interest borrowing rate. It is assumed that there are only two countries in this open economy model. One country has a low real interest rate, like Japan. The other one has a high real interest rate, like China. If there is real interest spread between the two countries (Figure 2), investors from low-deposit interest country will invest in the country with a higher deposit rate. This is a simple model of international capital flow. Borrowers will then have access to more finance at and lower borrowing rate (Figure 2, right panel)

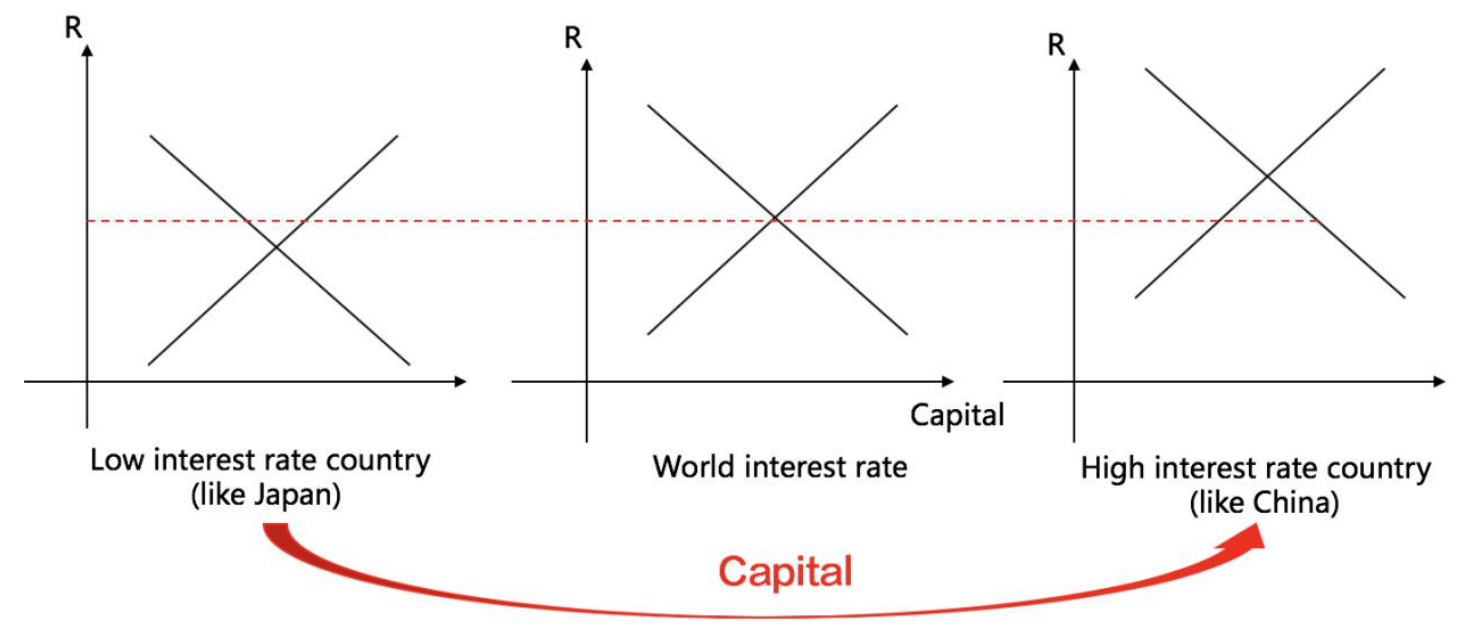

Figure 2. The influence path of financial liberalization on economy ${ }^{[6]}$.

In case of idealization, without considering the transactions costs of capital flows, capital can flow freely in the global capital market, and the return on capital is the same in all countries in the world under equilibrium. However, the existence of investment barriers between countries impedes capital flows, reducing the efficiency of capital use.

Barriers to investment may be of variety of forms, like foreign exchange control and restrictions on remittance of investment income. Although the underpinnings of each type of barrier differ, the ultimate effect of any barrier to investment is to raise the price of an effective unit of capital used in production.

Higher priced capital reduces the competitiveness of capital-using activities and lowers potential output. Reducing barriers to investment can therefore provide an incentive to increase investment activity as the cost of supplying a unit of effective capital is reduced.

After new foreign capital (Figure 3, Line CL) flows into domestic capital market, the availability of capital increases and the marginal products of capital will decline, reducing the cost of investment. At the same time, excessive capital inflows will depreciate domestic currency (Figure 3, from point D to K) and facilitate exports, thus promoting the growth of GDP. 


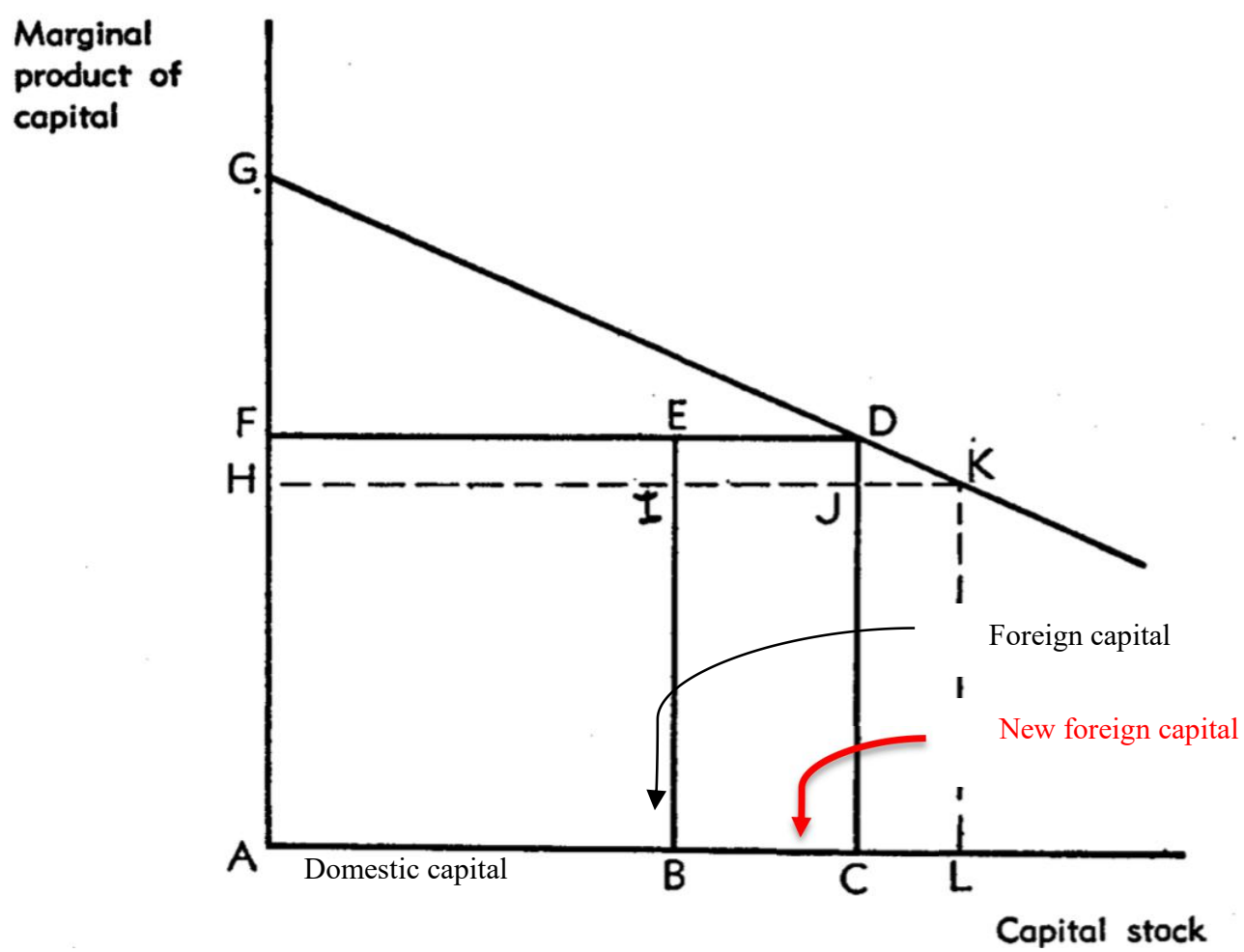

Figure 3. The influence of new foreign capital inflow ${ }^{[8]}$.

\subsection{Savings-to-investment transformation efficiency}

In the process of transforming savings into investment, financial liberalization can also affect the real economy through the transformation efficiency of savings. Financial frictions refer to the factors that increase transaction costs due to the imperfection of market information structure driving a wedge between lending and borrowing rates. There is transaction cost in the process of transforming savings into investment ${ }^{[4]}$, so investment is less than savings. Under the condition of financial restraint, the allocation of capital does not operate according to the regulation function of the market. The distortion caused by market failure may lead to a large amount of capital being left idle, unable to form effective capital circulation, and also bring much pressure on banks since the banks need to pay the depositors interest. Therefore, improving the efficiency of the financial system is also an important element of financial liberalization reform.

As shown in Figure 4, demand line implies investment side, like the growing firms which require investment funds. On the other side, supply side implies saving that banks and other financial institutions obtain from the public. They cross at a point which implies the real interest rate of this capital market if it is Pareto efficiency. In the process of indirect financing, financial institutions play the role of intermediary. Financial institutions get income through the spread between saving rate and loan rate. This income can be seen as a dead weight loss of depositors and lenders. If the efficiency of financial institutions can be improved, the interest rate difference between deposits and loans will be reduced, the dead weight loss of depositors and lenders will be reduced, and the welfare will be increased. 


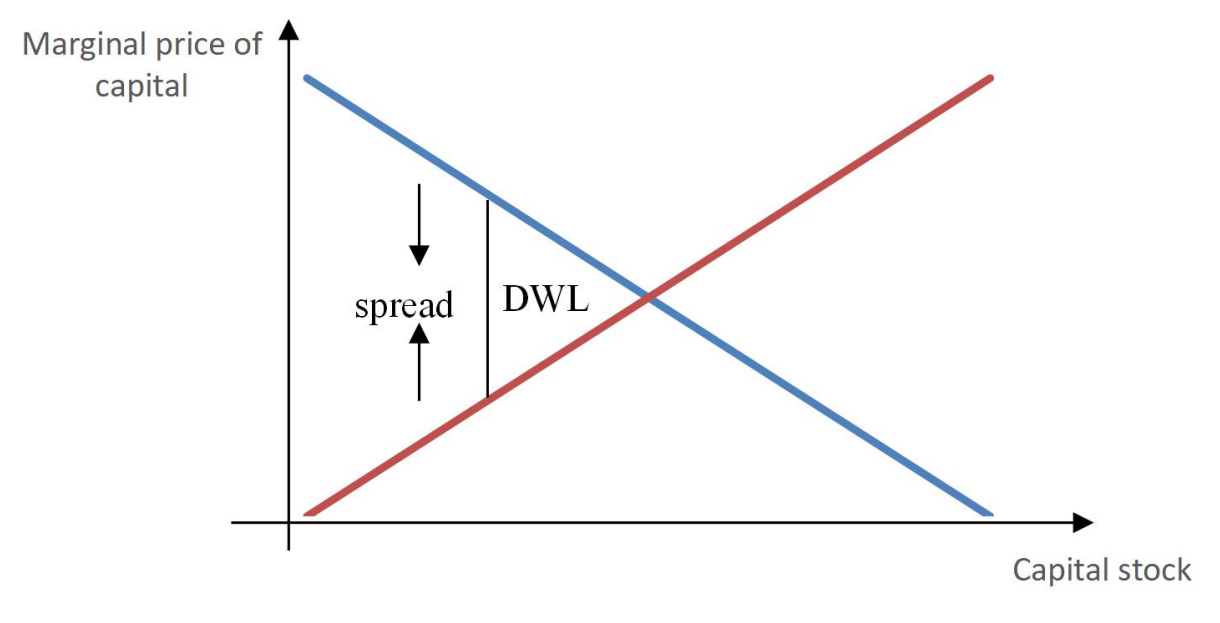

Figure 4. The dead weight loss between depositors and lenders.

\subsection{Investment efficiency}

Because of the different specific conditions, enterprises will inevitably have different efficiency in specific production technology and operation transformation, which will lead to different rate of return. In the capital market with financial repression, the newly developed high-profit enterprises may not get the capital they need but can only obtain it through informal channels (such as shadow banks) with higher cost, that is larger spreads between borrowing and lending rates. And inefficient state-owned enterprises can get subsidized loans at preferential prices on output, subsidies on inputs, or preferential access to scarce finance. This disguised subsidy for inefficient enterprises reduces the efficiency of capital allocation and impedes the effective operation of markets. However, a liberalized market can help eliminate such negative impacts. In the absence of government subsidies, inefficient enterprises cannot adapt to market operation, and eventually are squeezed out of the market system ${ }^{[1](124)}$.

\section{Analysis of China and Japan}

\subsection{Brief description}

As a large, developing country, China has many investment opportunities. The funds used for investment come from high domestic savings rate on the one hand, and foreign investment on the other. Real interest rate is an indicator of the cost of capital used for investment. According to the World Bank data, China's real interest rate was above 3\% from 2012 to 2016, which is at a high level in the world (Figure 5). The United States is chosen as the baseline. It can be found that the real interest rate of China is about 1 percentage point higher than that of the United States from 2012 to 2016. China's real interest rates are much higher than Japan's and in 2014 and 2015 the gap is about 5 percentage points. China's higher real interest rate means that the cost of capital used for investment is higher in domestic financial market, and it can attract foreign capital through high return on capital. 


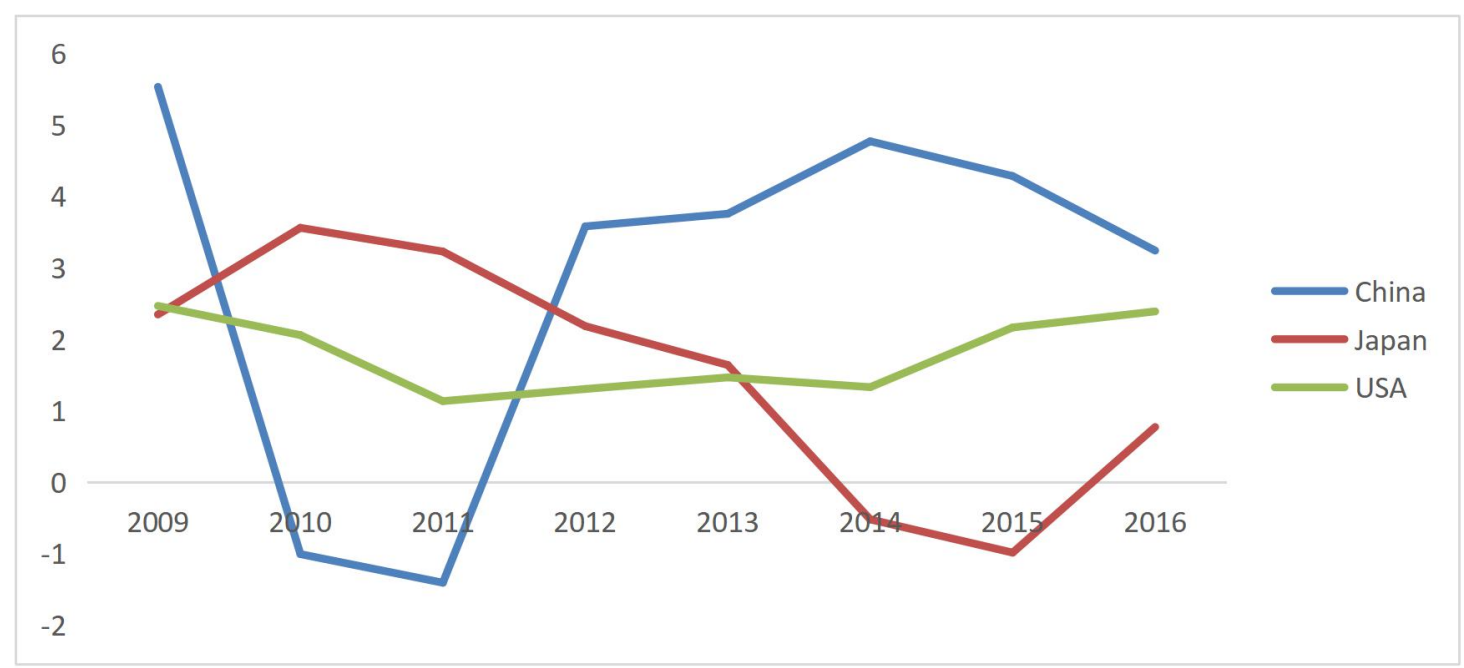

Figure 5. Real interest rate in China Japan and U.S from 2009 to 2016. (Data source: World bank $<$ https://data.worldbank.org/indicator/FR.INR.RINR>).

At present, China's financial market efficiency is lower than that of developed countries. This paper uses deposit and lending rate wedge as an indicator of financial market productive efficiency. In Figure 6, Canada is chosen as the benchmark because data from the United States were not available. From 2009 to 2014, the annual interest rate gap between deposit and loan in China is about 0.5 percentage points higher than that in Canada, which tends to narrow gradually in the following years. Japan's deposit and loan interest rate gap, which is about $1 \%$, is much lower than that of China and Canada, and shows a decreasing trend between 2009 and 2017. This suggests that Japan's financial market service provision is relatively more productive than the benchmark.

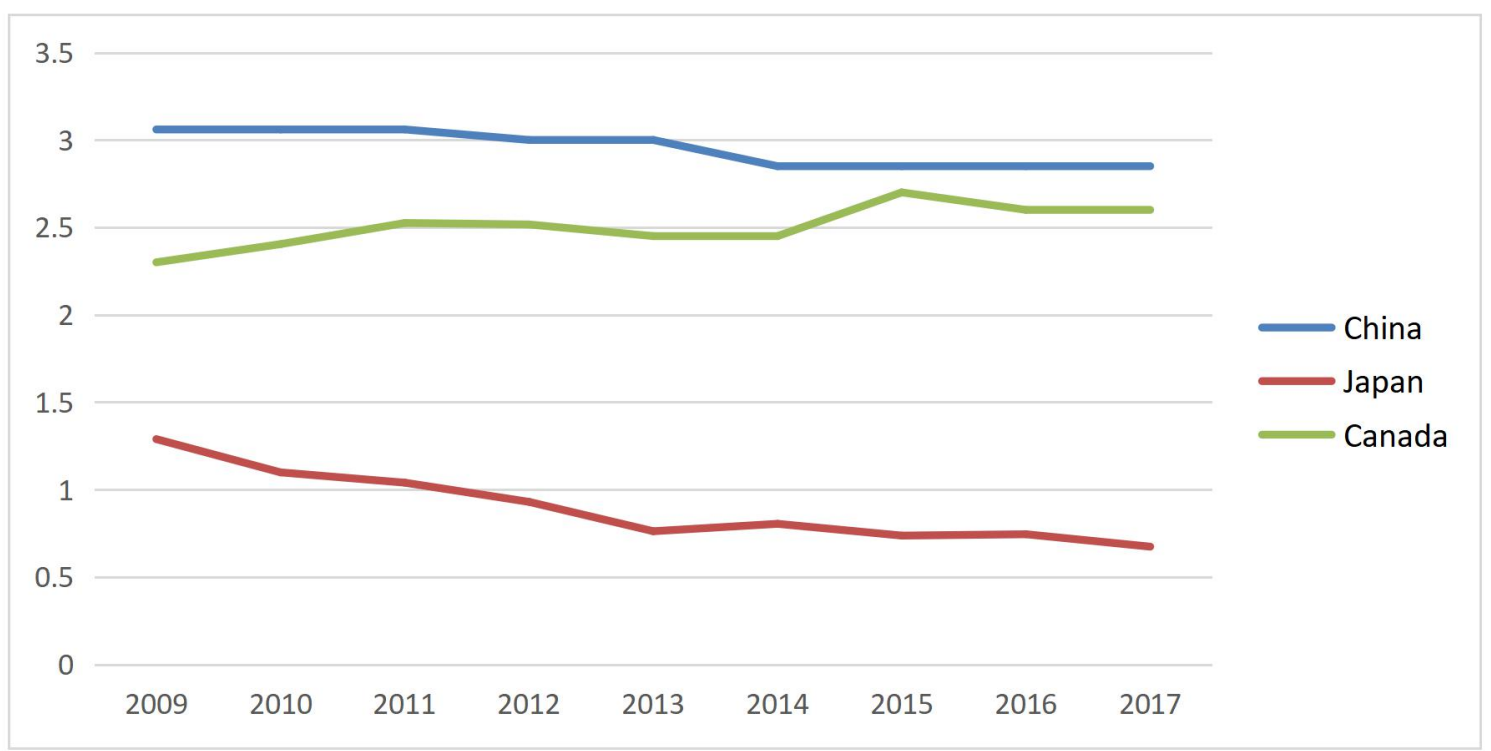

Figure 6. Deposit and lending rate wedge in China, Japan and Canada from 2009 to 2017. (Data source: World bank $<$ https://data.worldbank.org/indicator/FR.INR.LNDP>).

In recent years, the Japanese government has used the policy of quantitative easing to stimulate the economy, but the policy has limited effect. One reason for Japan's lack of momentum in economic growth is its inefficient use of capital, which can be seen from an index called "Ease of doing business" (Figure 7). Compared with other developed countries, Japan's index is much higher. The higher value means that it is not easy to do business in Japan. As a developing country, China has a slightly higher index than Japan. 


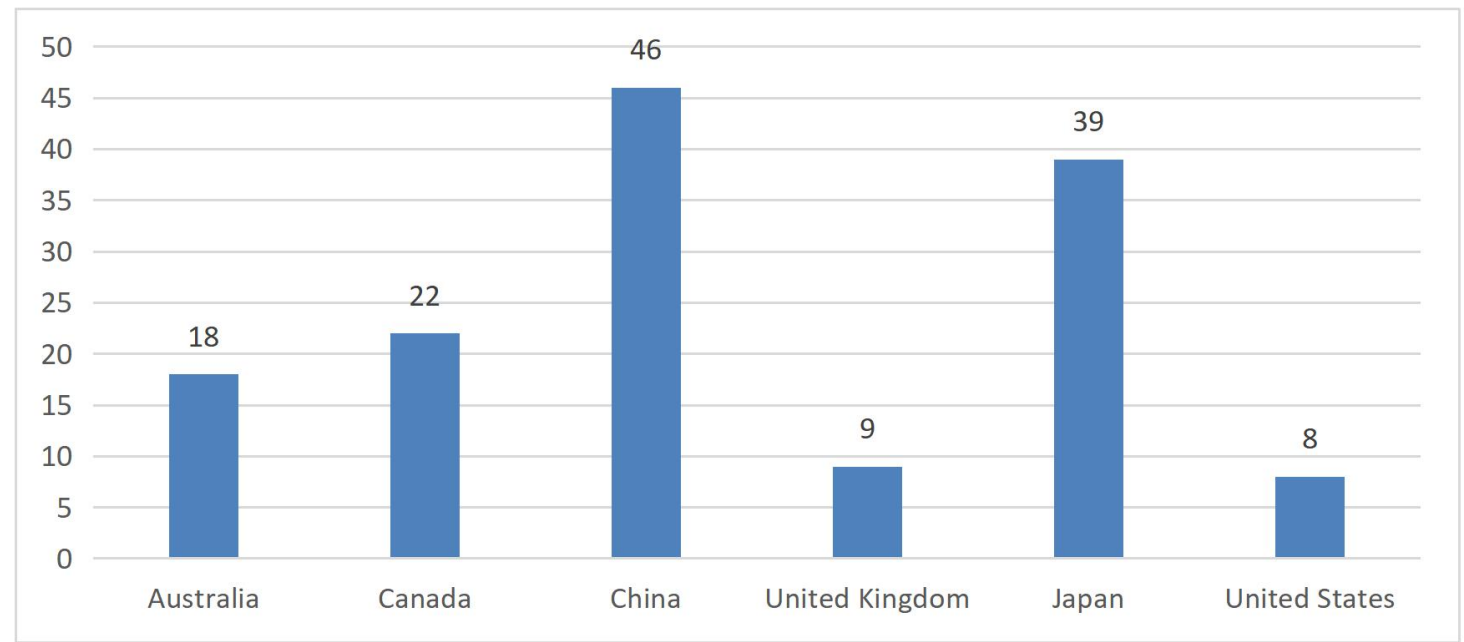

Figure 7. Ease of doing business index in 6 countries in 2018 (1=most business-friendly regulations). (Data Source: World bank $<$ https://data.worldbank.org/indicator/IC.BUS.EASE.XQ>).

Though the efficiency of capital use cannot be directly measured, it can be indirectly estimated by using labor productivity. As shown in Figure 8, China's labor productivity is far lower than that of Japan and the United States, and there is a gap between Japan and the United States, which means suggests that China and Japan have the potential to improve the efficiency of capital use across the economy. One policy means of achieving this is through effective reform that improves the efficiency of the allocation of real capital.

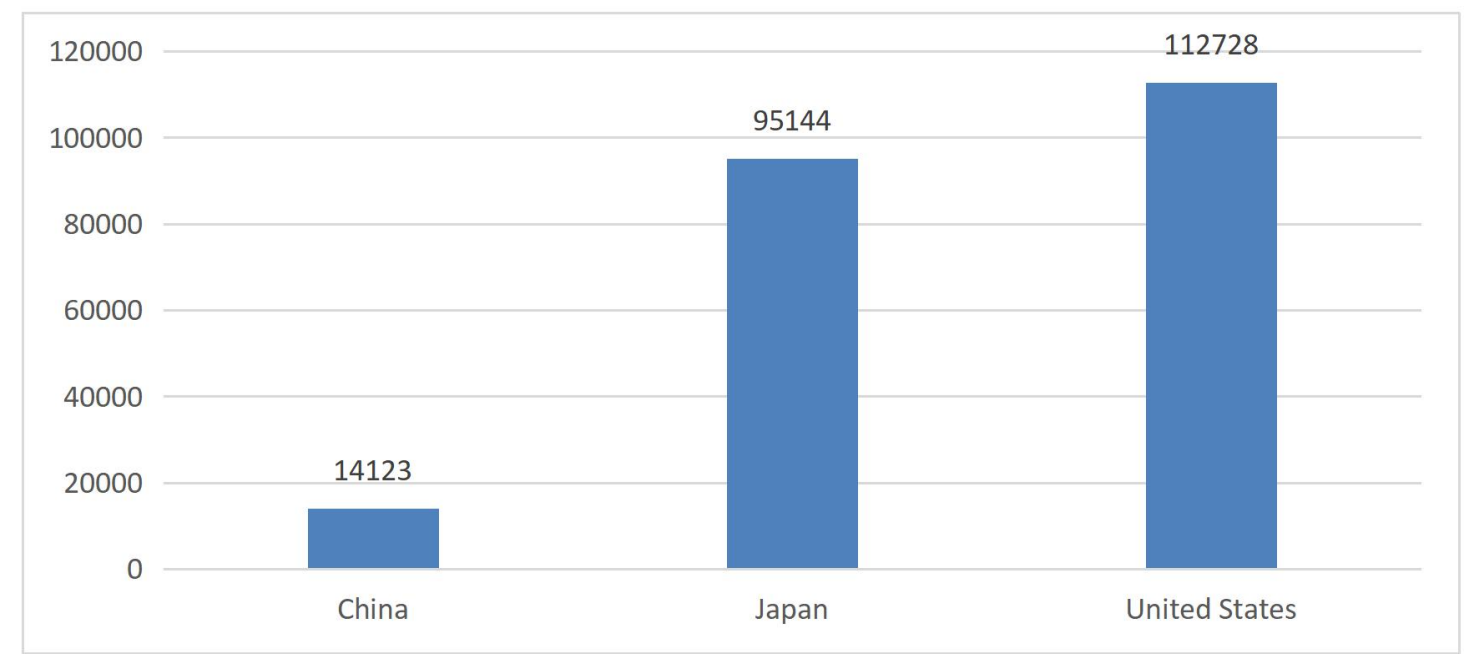

Figure 8. Labour productivity of China Japan and U.S. in 2018 (output per worker (constant 2010 US \$)). (Data source: International Labour Organization <https://www.ilo.org/ilostat-files/Documents/description_PRODY_EN.pdf $>$ )

\subsection{Simulation scenario}

Through the analysis for China and Japan, the potential financial market liberalization reforms for the two countries have been identified .

\subsubsection{Required rate of return (modelling investment barrier)}

China's high expected return on capital can attract foreign investment. If the investment barriers are reduced, the investment risk of foreign capital will be reduced. According to the formula of the capital asset pricing model (Equation 1), the required rate of return of foreign capital will also decrease ${ }^{[5]}$. Therefore, the reduction of investment barriers in capital market reform can be reflected in the reduction of required rate of return. 


$$
E R_{i}=R_{f}+\beta_{i}\left(E R_{m}-R_{f}\right)
$$

where $E R_{i}$ is expected return of investment, $R_{f}$ is risk-free rate, $\beta_{i}$ is beta of the investment (it is a coefficient measuring risk), $E R_{m}$ is expected return of market, $\left(E R_{m}-R_{f}\right)$ is Market risk premium.

In GTAP model, the projected (percentage) change in the rate at which capital is available is determined by shock, rorc(r), which means rate of return on capital. With $\mathrm{f}$ _rorc exogenous and shocked (and rorc_r exogenous) by equation:

$$
\operatorname{rorc}(r)=\operatorname{rorc}{ }_{-} f_{-} \operatorname{rorc}(r)
$$

The projected change in the rate at which capital is available is determined. By equation RORCURRENT:

$$
\operatorname{rorc}(r)=\operatorname{GRNETRATIO}(r) *[\operatorname{rental}(r)-\operatorname{pcgds}(r)]
$$

where GRNETRATIO(r) is the ratio of gross to net (after depreciation) returns to capital in region $\mathrm{r}$, rental(r) is the percentage change in the capital rental rate of return in region $r$, which depends on the factor income paid to capital, $\operatorname{pcgds}(r)$ is the price of investment goods in region $\mathrm{r}^{[10](\mathrm{p55})}$.

In the GTAP model, a change in the rate at which capital is available is equilibrated with the change in the rate at which it is used. Assuming that GRNETRATIO(r) and pcgds(r) are both fixed, a decrease of rorc(r) will result in the decrease of rental(r) through an increase in capital employed and a lowering of the rental price. This relation defines the longer-run focus of this study.

\subsubsection{Improvement in productivity of financial service provision and capital used in all industries}

Financial market reform could also affect the productivity of financial service provision and the productivity of capital used in production. From the analysis of China and Japan, it can be found that the two countries have the potential to improve the efficiency in financial service provision and industrial capital use through Japan's financial sector is highly efficient. The table below summarizes the GTAP variables that could be considered as part of a modelling scenario and the description of the codes and the intuition of each shock.

\begin{tabular}{|l|c|}
\hline \multicolumn{2}{|c|}{ Productivity of financial service provision } \\
\hline $\begin{array}{l}\text { Improvement in productivity of value adding input } \\
\text { use in financial service provision }\end{array}$ & Shock avaall \\
\hline $\begin{array}{l}\text { Improvement in the productivity of intermediate } \\
\text { input use in financial service provision }\end{array}$ & Shock afall \\
\hline \multicolumn{2}{|c|}{ Productivity of capital used in all industries } \\
\hline $\begin{array}{l}\text { Improvement in the productivity of capital in all } \\
\text { industries }\end{array}$ & Shock afeall \\
\hline
\end{tabular}

Table 1. The GTAP model variable of the productivity shock in financial service and capital use

These exogenous technology variables are included in the modelling of product and factor prices, and output (in percentage changes) according to the following relations.

$$
\begin{gathered}
p v a(j, r)=\sum S V A(j, r) \times[p f e(j, r)-a f e(j, r)] \\
q f e(i, j, r)+a f e(i, j, r)=q v a(j, r)-\sigma_{V A}(j)=[p f e(i, j, r)-a f e(i, j, r)-p v a(j, r)] \\
q v a(j, r)+a v a(j, r)=q o(j, r)-a o(j, r) \\
q f(i, j, r)+a f(i, j, r)=q o(j, r)-a o(j, r)
\end{gathered}
$$

Equations (4) and (5) describe the nesting of technology trees in which producers invest in production factors. They specifically explain the price changes of composite factors $(p v a)$ and the changes of enterprises' demand for factor endowments in each sector $(j)$. Here, the coefficient $s v a(i, j, r)$ refers to the proportion of factor endowment commodity (i) in the total input cost in the sector (j) of region ( $\mathrm{r}$ ). In addition to the price variable $p f e(i, j, r)$, the equation also includes the variable $a f e(i, j, r)$, which represents the technological innovation rate of factor input expansion. Note that $a f e(i, j, r)$ is the rate of change of variable $a f e(i, j, r)$, where $a f e(i, j, r) \times q f e(i, j, r)$ is equal to 
the effective input to the original element $\mathrm{i}$ in regional $\mathrm{r}$ sector $\mathrm{j}$. Therefore, if $a f e(i, j, r)>0$, the effective price of factor $\mathrm{i}$ will decrease. For these reasons, $p f e(i, j, r)$ needs to be deducted from afe $(i, j, r)$ which leads to the following effects:

Through the right half of equation (5), production factor $i$ is used to replace other factors. Through the left half of equation (5), the demand for factor I is reduced (when the effective price is constant).

Equation (4) is used to reduce the cost of composite elements, thus promoting the expansion of enterprises and increasing the demand for all elements for a given level of real factor inputs.

In equation (6) and (7), the variables $a v a(j, r)$ and $a f(i, j, r)$ refer to the expanding technological innovation on values-added and intermediate inputs, respectively. The variable ao (j, r) refers to Hicks' neutral technological innovation, which uniformly reduces the restriction on factor input under the condition of given output. With the other variables fixed, the increase of $a v a(j, r)$ and $a f(i, j, r)$ will result the increase of $q o(j, r)$, which is the quantity of products. It means if there is productivity improvement of input use in financial service provision and capital use in all industries, the output will increase ${ }^{[10](\mathrm{p} 41-45)}$.

\section{Methodology and data}

\subsection{GTAP model}

This paper uses the comparative static version global trade analysis project (GTAP) model to simulate the potential changes of GDP, net export and welfare level of China and Japan from effective financial market liberalization policies. GTAP is a multi-regional and multi-sectoral general equilibrium model, which can flexibly analyze the changes of international trade price and quantity brought about by tariff reduction, free trade area, trade and subsidy policy adjustment, as well as the changes of economic and welfare indicators of various countries ${ }^{[10]\left(p^{13}\right)}$.

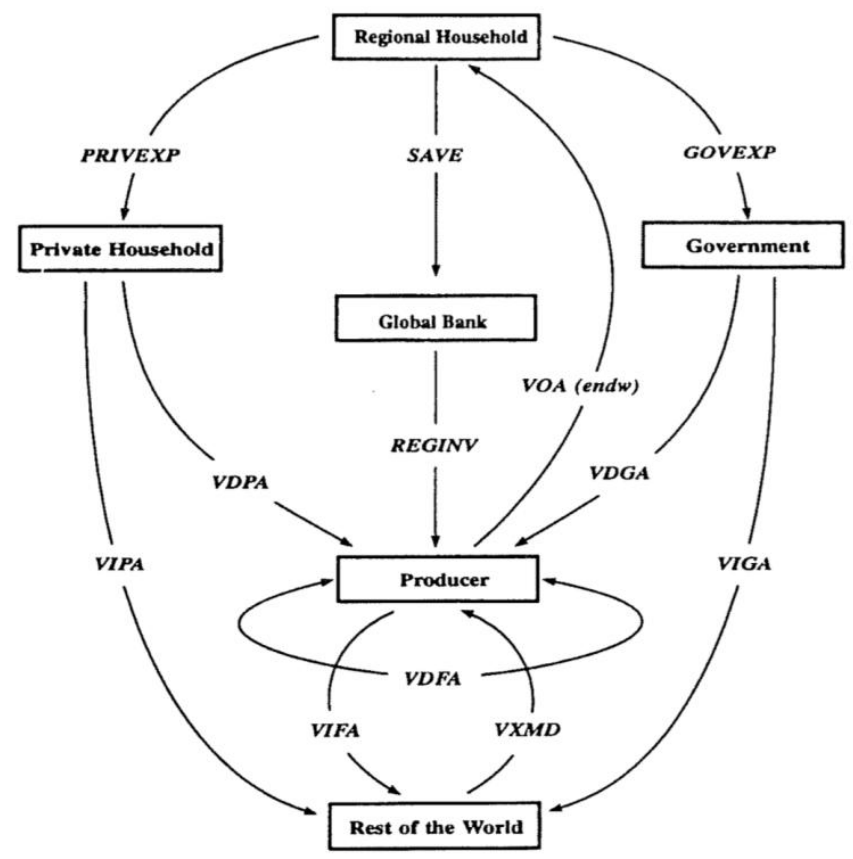

Figure 9. Structure of GTAP model ${ }^{[10](\mathrm{p} 17)}$.

In Figure 9, at the top is the regional household account, whose expenditure is allocated by a total utility function and has three directions: private consumption expenditure, government expenditure and savings. In the standard closed model, the Cobb Douglas utility function of regional accounts ensures a fixed share of each type of expenditure. The only source of residents' income in regional accounts is to sell factor endowment (VOA) to manufacturers. Manufacturers combine these factor endowments with intermediate goods (VDFA) to produce goods to meet the final 
demand. The final demand includes private consumption (VDPA), government consumption (VDGA) and investment goods regional accounts (REGINV) sold to meet the savings demand of regional accounts.

Rest of world (ROW) is the import source of regional economy, and also the export destination (VXMD is the export value divided by destination). In the domestic economy, the import is traced back to the specific exporter, which leads to different payments of private consumption (VIPA), government consumption (VIGA) and manufacturer (VIFA) for import.

The world bank acts as an intermediary between global savings and regional investment. It gathers a series of regional investment product portfolio (REGINV), and then sells some products in the portfolio to regional account residents to meet their saving needs.

\subsection{Data}

The simulations in this paper are based on GTAP database (9th edition), the reference year 2011.

According to the needs of analysis, the original 129 countries (regions) in GTAP database are summarized into six groups, namely Australia, China, Japan, the United States, EU 28 countries and ROW (rest of the world). The original 57 industrial groups in GTAP database are aggregated into 13 industrial sectors. The 5 primary factor inputs are land, natural resources, skilled labour, unskilled labour and capital.

\subsection{Derivation of shocks}

Two sets of data were used to determine the magnitude of the shock on required rate of return. The first set of data is GTAP data (Table 2). By comparing the net return on capital of China and the United States, the difference between the return on capital of China and the United States can be calculated in Table 2. The shock on required rate of return should be set to 14.66 to close $1 / 3$ of the return rate wedge between China and the U.S.

\begin{tabular}{|c|c|c|c|c|c|c|c|c|c|}
\hline & $\begin{array}{c}\text { Gross } \\
\text { receipts } \\
\text { on } \\
\text { capital }\end{array}$ & Depreciation & $\begin{array}{c}\text { Net } \\
\text { returns } \\
\text { to } \\
\text { capital }\end{array}$ & $\begin{array}{c}\text { Value of } \\
\text { installed } \\
\text { capital }\end{array}$ & $\begin{array}{c}\text { Gross } \\
\text { rate of } \\
\text { return }\end{array}$ & $\begin{array}{c}\text { Net rate } \\
\text { of return }\end{array}$ & $\begin{array}{c}\text { Points } \\
\text { difference } \\
\text { from the } \\
\text { US }\end{array}$ & $\begin{array}{c}\text { Close 1/3 } \\
\text { of the } \\
\text { difference }\end{array}$ & Percentage \\
\hline & $\begin{array}{c}\text { USD } \\
\text { mill. }\end{array}$ & USD mill. & $\begin{array}{c}\text { USD } \\
\text { mill. }\end{array}$ & USD mill. & $\%$ & $\%$ & pp & pp & $\%$ change \\
\hline China & 2642362 & 1040756 & 1601606 & 26018896 & 10.16 & 6.16 & 2.71 & 0.90 & 14.66 \\
\hline USA & 3579879 & 1922722 & 1657157 & 48068048 & 7.45 & 3.45 & 0.00 & 0.00 & 0.00 \\
\hline
\end{tabular}

Table 2. The determination of the RRR shock by GTAP data. (Source: Author estimates from GTAP9a model and data base).

Another set of data is the real interest rate (Table 3). The point difference of real intertest rate between the two countries is 1.366 . If we want to close $1 / 3$ of the return rate wedge between China and the U.S, the shock required rate of return should be set to 14.632 .

\begin{tabular}{|c|c|c|c|c|}
\hline & Real interest rate & $\begin{array}{c}\text { Points difference } \\
\text { from the US }\end{array}$ & $\begin{array}{c}\text { Close one third of } \\
\text { the difference }\end{array}$ & Percentage \\
\hline & $\%$ & $\mathrm{pp}$ & $\mathrm{pp}$ & $\%$ change \\
\hline China & 3.112 & 1.366 & 0.455 & 14.632 \\
\hline USA & 1.746 & 0.000 & 0.000 & 0.000 \\
\hline
\end{tabular}

Table 3. The determination of the RRR shock by real interest rate. (Source: Author estimates real interest rate data from World Bank).

It can be seen that the calculated result is very close by the two data set. In summary, the required rate of return shock is determined to be 15 , narrowing $1 / 3$ of the investment barrier wedge. 
For the other two productivity improvement scenarios, the shock is set to be uniform one, which is the standard unit in GTAP system.

\section{Simulation result}

\begin{tabular}{|c|c|c|c|}
\hline \multicolumn{2}{|c|}{ Simulation } & \multicolumn{2}{c|}{ Change of GDP } \\
\cline { 2 - 4 } \multicolumn{2}{|c|}{} & CHN & JPN \\
\hline \multirow{3}{*}{ China } & 90 basis point reduction in the RRR on capital & 6.18 & -0.02 \\
\cline { 2 - 4 } & uniform 1 improvement in productivity of financial service provision & 0.08 & -0.00 \\
\cline { 2 - 4 } & uniform 1 improvement in productivity of capital used in all industries & 0.71 & -0.01 \\
\hline \multirow{3}{*}{ Japan } & uniform 1 improvement in productivity of financial service provision & -0.00 & 0.11 \\
\cline { 2 - 4 } & uniform 1 improvement in productivity of capital used in all industries & -0.00 & \multirow{2}{*}{0.79} \\
\hline
\end{tabular}

Table 4: The simulation result of GDP. (Source: Author estimates from GTAP9a model and data base)

After lowering investment barriers, which is presented by the reduction in required rate of return in GTAP model, more capital will flow into China and investment will increase. China's GDP is projected to increase substantially due to the increase of investment. According to the simulation, a reduction in the gap between China and the United States required returns on capital of one third (equivalent to 15 basis points), is projected to raise China's GDP by $6.18 \%$.

The improvement of financial industry productivity is a manifestation of financial development. The expansion of financial transaction scale and the process of financial industry upgrading can bring about the continuous improvement of financial efficiency. It is reflected in the elimination of financial repression and the improvement of financial structure, that is, the innovation of financial instruments and the diversification of financial institutions to adapt to economic development ${ }^{[7]}$.

The efficiency of using funds in the industrial sector reflects the total factor productivity, which is a productivity index to measure the total output per unit of total investment. It is often regarded as an indicator of scientific and technological progress, and its sources include technological progress, organizational innovation, specialization and production innovation.

Improving the productivity of financial service delivery and the productivity of capital across all industrial sectors will have a positive impact on the economy of China and Japan. For China, increasing uniform 1 productivity of the financial sector can lead to an increase of GDP by 0.08 , while increasing the productivity of the industrial sector of uniform 1 can lead to an increase of GDP by 0.71 . For Japan, the two types of productivity increases can potentially bring 0.11 and 0.79 GDP growth, respectively. Under the same level of shock, the potential effect of improving the efficiency of capital use in all industrial sectors is the more significant.

According to the previous analysis, China's financial sector efficiency is slightly lower than that of developed countries, but the gap is not large. The efficiency of Japan's financial sector is even much higher than that of other developed countries. However, the time series analysis above indicates China and Japan's industrial sectors are less efficient in using capital than other developed countries. The results suggest that if this gap is reduced, China and Japan could achieve substantial economic gains and have potential in improving efficiency of capital used.

\begin{tabular}{|c|c|c|c|}
\hline \multicolumn{2}{|c|}{ Simulation } & \multicolumn{2}{c|}{ Change of Net Export } \\
\cline { 3 - 4 } \multicolumn{2}{|c|}{} & CHN & JPN \\
\hline China & 90 basis point reduction in the RRR on capital & 166861.9 & -17885.6 \\
\hline
\end{tabular}

Table 5. The simulation result of Net Export. (Source: Author estimates from GTAP9a model and data base). 
Reducing investment barriers means reducing investment risk, which can attract foreign capital inflow. MacDougall argues that the inflow of foreign capital will increase the availability of capital, decrease the marginal products of capital and devalue the domestic currency, which is conducive to export ${ }^{[8]}$. As shown from the simulation results, China's net export is expected to increase by 16.69 million US dollars (2011 benchmark values). Some products exported by China and Japan are fungible, so the reduction of China's investment barriers will reduce Japan's net exports by 1.79 million US dollars.

\begin{tabular}{|c|c|c|c|}
\hline \multicolumn{2}{|c|}{ Simulation } & \multicolumn{2}{c|}{ Change of Real Income } \\
\cline { 3 - 4 } \multicolumn{2}{|c|}{} & CHN & JPN \\
\hline \multirow{3}{*}{ China } & 90 basis point reduction in the RRR on capital & 3.85 & -0.04 \\
\cline { 2 - 4 } & uniform 1 improvement in productivity of financial service provision & 0.1 & -0.00 \\
\cline { 2 - 4 } & uniform 1 improvement in productivity of capital used in all industries & 0.67 & -0.01 \\
\hline \multirow{3}{*}{ Japan } & uniform 1 improvement in productivity of financial service provision & 0 & 0.12 \\
\cline { 2 - 4 } & uniform 1 improvement in productivity of capital used in all industries & -0.00 & 0.83 \\
\hline
\end{tabular}

Table 6. The simulation result of Real Income. (Source: Author estimates from GTAP9a model and data base)

According to the Solow-Swan model, total output is used to pay the capital rent and labor wage. With the increase of total output, the income of workers will rise. It can be seen from the simulation results that after reducing the basis point in investment barriers, the real income of Chinese residents is expected to increase by $3.85 \%$. Improving the efficiency of financial industry and capital use will also increase the real income of residents and the growth rate in real income is close to the growth rate of GDP.

\section{Conclusion}

\subsection{Main conclusion}

Financial market liberalization is expected to bring substantial economic benefits to China and Japan. The reduction of investment barriers will increase the inflow of foreign capital in China, contribute to China's commodity exports, and thus promote the growth of GDP. China's GDP is expected to increase by $6.18 \%$ and real income is expected to increase by $3.85 \%$ if China reduces the investment barrier that is $1 / 3$ of the gap between China and the United States.

Financial reform plays an important role in promoting economic development. The improvement of production efficiency in the financial sector can help to improve the efficiency of capital allocation, thus promoting the increase of output. For every $1 \%$ increase in financial industry productivity, China's GDP is expected to increase by $0.08 \%$, and the national real income is expected to increase by $0.1 \%$. Japan's GDP is expected to increase by $0.11 \%$ and its real income is expected to increase by $0.12 \%$.

The capital used for investment will flow into the industrial sector. The improvement of industrial sector's use of capital productivity can contribute to the increase of output. For every $1 \%$ increase in industrial sector productivity, China's GDP is expected to increase by $0.71 \%$ and the national real income is expected to increase by $0.67 \%$. Japan's GDP is expected to increase by $0.79 \%$ and the national real income is expected to increase by $0.83 \%$.

\subsection{Limitations of study and further scope}

In this paper, the derivation of stock is not rigorous enough. The best way is to use econometric method to model and predict through three groups of data. In addition, the description of the simulation results is not detailed enough.

In the later research, dynamic GTAP model can be introduced to explain the impact process of shock on the research object. Moreover, the analysis of three simulation scenarios and results can be specific to the policy level. 


\section{References}

1. Chang L. Analysis of inflation and monetary policy in China from 2010 to 2011 (in Chinese). Southwest University of Finance and Economics; 2012.

2. Goldsmith RW. Financial structure and development. New Haven and London. Yale University Press; 1969. doi: $10.2307 / 3654543$.

3. Gretton P. Modelling the potential impacts of economic reform in a partnership between Australia and China. Eaber Working Paper Series; 2016.

4. Kagan J. Investopedia 2018. Available from: https://www.investopedia.com/terms/f/frictioncost.asp.

5. Kenton W. Investopedia 2019. Available from: https://www.investopedia.com/terms/c/capm.asp.

6. Krugman PR, Obstfeld M, Melitz MJ. International economics theory \& policy. $9^{\text {th }}$ ed. 2010.

7. Li W. Financial dictionary. Heilongjiang People's Publishing House; 2002.

8. MacDougall GDA. The benefits and costs of private investment from abroad: A theoretical approach. The Economic Record 1960; 36(73): 13-35. doi: 10.1111/j.1475-4932.1960.tb00491.x.

9. McKibbin WJ. Financial reforms and consequence of changing risk perceptions in APEC economies. Brookings Discussion Papers in International Economics 1999; (148).

10. Thomas H, Powell A, Frisvold G. Global trade analysis: Modeling and applications. Cambridge University Press; 1997.

11. McKinnon RI. Money and capital in economic development. Washington, D.C.: The Brookings Institution; 1973. doi: $10.2307 / 1960040$.

12. Shaw ES, Cole DC. Financial deepening in economic development. New York: Oxford University Press; 1973. doi: $10.2307 / 2978421$.

13. Stiglitz JE. Capital market liberalization, economic growth, and instability. World Development 2000; 28(6): 1075-1086. doi: https://doi.org/10.1016/S0305-750X(00)00006-1.

14. Wang W. The research on Harold-Doma economic growth (in Chinese). 2011. 